\title{
Sistem Pendukung Keputusan Pemilihan Calon Paskibraka Di Provinisi Riau
}

\author{
Nesi Syafitri ${ }^{1}$, Muhammad Prayogi ${ }^{2}$, Ause Labellapansa ${ }^{3}$ \\ Program Studi Teknik Informatika, Fakultas Teknik, Universitas Islam Riau \\ e-mail: ${ }^{1}$ nesisyafitri@eng.uir.ac.id, ${ }^{2}$ muhammad.prayogi27@yahoo.com, \\ 3ause.labella@eng.uir.ac.id
}

\begin{abstract}
National Paskibraka Selection is an activity who organized by Dispora of Riau Province. Every year to selection the best candidates to have duty as flag raisers of Bendera Pusaka in Istana Negara on celebration Hut RI. At selection of National Paskibraka candidates the are many weakness the committee of national paskibraka selection still used manual metron to determine final score every candidate from step of test. To estimate step of tes white more candidates will complicate committee to in appraise and make a decision to cope that problem, need a decision system application support would give an information about estimate of selection exactly and arcurate.
\end{abstract}

Keywords: Decision system support,Flag raisers. Selection, Paskibraka.

\section{Abstrak}

Seleksi Paskibraka Nasional adalah suatu kegiatan yang dilaksanakan oleh Dispora Provinsi Riau. Pada setiap tahunnya yang bertujuan untuk mencari putra putri terbaik yang akan ditugaskan sebagai pengibar bendera pusaka di Istana Negara pada perayaan Hut RI. Pada seleksi pemilihan calon Paskibraka Nasional masih banyak terdapat kekurangan. Panitia seleksi Paskibraka Nasional masih menggunakan cara manual dalam menentukan nilai akhir setiap peserta dari seluruh tahapan test yang diselenggarakan. Penilaian tahapan test dengan jumlah peserta yang tergolong banyak akan menyulitkan panitia dalam pertimbangan penilaian dan pengambilan keputusan. Untuk mengatasi masalah itu, diperlukan aplikasi sistem pendukung keputusan yang dapat memberikan informasi penilaian seleksi berdasarkan kriteria penilaian yang telah ditetapkan secara tepat dan akurat.

Kata kunci: Seleksi, Sistem Pendukung Keputusan, Paskibraka, Pengibar Bendera

\section{PENDAHULUAN}

Pasukan Pengibar Bendera Pusaka atau yang lebih sering dikenal dengan Paskibraka, merupakan suatu pasukan yang bertugas dalam mengibarkan duplikat Bendera Pusaka dalam upacara peringatan proklamasi kemerdekaan indonesia pada tanggal 17 agustus yang diselenggarakan di tiga tempat, yakni tingkat Kabupaten/Kota (Kantor Bupati/Walikota), Provinsi (Kantor Gubernur), dan tingkat Nasional (Istana Negara)[1].

Untuk tingkat Kota dan Kabupaten, dalam proses pemilihannya akan dipilih calon anggota Pasukan pengibar Bendera Pusaka yang berasal dari pelajar SMA sederajat kelas 1 atau kelas 2 melalui proses seleksi. Proses ini dilakukan secara bertahap dan ketat oleh panitia penyeleksi sehingga pada akhirnya akan terpilih anggota Paskibraka yang berkualitas dan memenuhi standar agar siap untuk melakukan tugasnya sebagai Pasukan 
Pengibar Bendera Pusaka dengan baik. Untuk setiap Kabupaten/kota yang ada di Provinsi ini, akan dikirim 4 sampai 6 orang perwakilan yang terdiri dari 2 sampai 3 pelajar putra dan 2 sampai 3 pelajar putri yang akan bertugas di Provinsi. Setelah terkumpul semua perwakilan dari setiap Kabupaten/Kota, di Provinsi akan dilakukan proses seleksi kembali yang akan dikirim ke tingkat Nasional. Setiap Provinsi akan mengirim 2 orang pelajar, terdiri dari 1 pelajar putra dan 1 pelajar putri yang akan mewakili Provinsi.

Dalam seleksi pemilihan anggota Paskibraka ini, dilakukan dengan melakukan seleksi langsung oleh panitia seleksi yang terdiri beberapa unsur dari DISPORA, PPI, KNPI dan lain sebagainya.

Analitical Hierarchy Process merupakan metode pengambilan keputusan multi kriteria dalam masalah yang kompleks dengan mengkombinasikan faktor-faktor kualitatif dan kuantitatif untuk menentukan prioritas, Analitical Hierarchy Process (AHP) merupakan metode pengambilan keputusan yang dapat menyelesaikan masalah-masalah seperti pemilihan kebijakan, penentuan alternatif dan penyusunan prioritas. Metode AHP dapat memberikan sebuah prediksi hasil keputusan atas permasalahan yang ada melalui perbandingan nilai kepentingan antara satu elemen dengan elemen lainnya.

Dari permasalah tersebut maka metode Analitical Hierarchy Process (AHP) dapat digunakan dalam penelitian ini, untuk menentukan peserta mana yang layak untuk dikirim ke Istana Negara dari perwakilan Riau.

Sesuai dengan latar belakang diatas penulis tertarik untuk menggangkat menjadi sebuah judul penelitian dan pembuatan tugas akhir yaitu "Sistem Pendukung keputusan Pemilihan Paskibraka Nasional di Provinsi Riau dengan Metode AHP".

\section{Tujuan Pembuatan Sistem}

Adapun tujuan penelitian yang ingin dicapai dari penelitian tugas akhir ini adalah menerapkan metode AHP kedalam sistem pendukung keputusan untuk pemilihan calon anggota Paskibraka Nasional di Provinsi Riau.

\section{Tinjauan Pustaka}

Dalam penelitian yang dilakukan oleh M. Fairuz Reza (2014). Pada penelitian ini terdapat latar belakang masalah yaitu bagaimana membuat suatu sistem menyeleksi calon Paskibraka Pekanbaru dengan menggunakan metode fuzzy milty atribut decision making. Kelebihan sistem ini yaitu menghasilkan suatu aplikasi pemilihan paskibraka di Kabupaten Simalungun Utara menggunakan Metode simple additive weighting agar pemilihan menjadi akurat dan efesien. Sistem ini memiliki kekurangan yaitu pada sistem ini hanya dapat digunakan di Kabupaten Simalungun Utara.

Letak perbedaan dengan penelitian yang saya buat adalah pada penggunaan metode penelitiannya, tempat penelitian atau instansi dan kasus penelitian [2].

Penelitian lainnya adalah sistem pendukung keputusan pemilihan objek wisata, yang dilakukan oleh Muammar Arie Fauzan (2010) yang membahas tentang pemanfaatan metode AHP untuk pemilihan objek wisata di kota Surabaya. Dari penelitian tersebut maka dapat ditemukan suatu permasalahan yaitu banyaknya orang yang ingin berwisata namun tidak mengetahui informasi tentang tempat-tempat berwisata di kota Surabaya, oleh karena itu betapa pentingnya memilih objek wisata yang tepat, maka dibutuhkan sebuah sistem dalam bidang kepariwisataan. Solusi yang didapat dari penelitian di atas maka dapat di temukan sistem pendukung keputusan yang dapat membantu memberikan informasi dan pengambilan keputusan pemilihan obyek wisata secara efektif [3].

Penelitian yang dilakukan oleh Idam Kusomo W (2011). Membahas tentang pemanfaatan metode AHP (analytical hierarchy process) dalam membangun sistem pendukung keputusan pemilihan fakultas di perguruan tinggi berbasis mobile. Dari 
penelitian tersebut maka dapat ditemukan suatu permasalahan yaitu mengenai pemilihan fakultas oleh para siswa yang ingin melajutkan keperguruan tinggi namun mereka bingung untuk memilih fakultas apa yang cocok dengan mereka. Solusi yang didapat dari penelitian diatas maka dapat di temukan sistem pendukung keputusan yang dapat membantu memberikan saran kepada siswa mengenai fakultas apa yang paling cocok dengan mereka dan dapat diakses secara mobile web [4].

\subsection{Pengumpulan Data}

\section{METODOLOGI PENELITIAN}

Dalam proses pembuatan sistem pendukung keputusan pemilihan calon paskibraka nasional ini, diperlukan data-data pendukung yang benar dan akurat, oleh karena itu adapun beberapa teknik pengumpulan data yang dilakukan pada penelitian ini adalah sebagai berikut :

1. Wawancara (Interview)

Wawancara dilakukan dengan salah satu panitia seleksi paskibraka. Dalam proses wawancara tersebut dilakukan proses tanya jawab mengenai hal-hal terkait dengan proses pemilihan calon paskibaka, seperti kriteria apa saja yang menjadi penilaian, kemudian proses penilaian.

2. Pengumpulan Data

Data-data yang diperlukan akan dikumpulkan berdasarkan hasil dari wawancara dan melakukan survei ke lapangan. Data yang diperoleh yaitu nilai dari setiap kriteria, nama-nama kriteria yang digunaka. Dari hasil pengumpulan data, data tersebut akan digunakan sebagai acuan untuk membangun sistem baru yang dapat diimplementasikan.

3. Penelitian Kepustakaan

Dalam melaksanakan penelitian kepustakaan, penulis melakukan pencarian bahan pada buku yaitu buku paskiraka, artikel, dan searching internet. Hal tersebut sangat berguna untuk pedoman perancangan sistem dan referensi penulis terkait dengan pemilihan calon paskibraka nasional.

\section{2 Konsep Teori}

\subsubsection{Pasukan Pengibar Bendera Pusaka(Paskibraka)}

Paskibraka merupakan suatu pasukan yang bertugas dalam mengibarkan duplikat bendera pusaka dalam upacara peringatan proklamasi kemerdekaan Indonesia pada tanggal 17 agustus yang diselenggarankan di tiga tempat, yakni tingkat Kabupaten/Kota (kantor Bupati/Walikota), Provinsi (Kantor Gubernur) dan Nasional (Istana Negara) [5].

\subsubsection{Sitem Pendukung Keputusan}

Pengambilan keputusan adalah sebuah proses memilih tindakan (diantara berbagai alternatif) untuk mencapai suatu tujuan atau bebarapa tujuan. Menurut Simon (1977), pengambilan keputusan manajerial sinonim dengan proses keseluruhan dari manajemen[6].

\subsubsection{Analytical hierarchy process $(A H P)$}

AHP adalah salah satu metode dalam pengambilan keputusan yang menggunakan beberapa variabel dengan proses analisis bertingkat. Analisis dilakukan dengan memberi nilai prioritas dari tiap-tiap variabel, kemudian melakukan perbandingan berpasangan dari variabel-variabel dan alternatif-alternatif yang ada [7]. 


\subsubsection{Data Flow Diagram (DFD)}

Diagram Alir Data (DAD-DFD/Data Flow Diagram) adalah gambaran aliran data dari sumbernya yang memperlihatkan data dari sumbernya dalam objek kemudian melewati sebuah proses menuju ke tujuan lain yang ada pada objek lain[8]. DFD sering digunakan untuk menggambarkan suatu sistem yang telah ada atau sistem baru yang akan dikembangkan secara logika tanpa mempertimbangkan lingkungan fisik dimana data tersebut mengalir atau lingkungan fisik dimana data tersebut akan di simpan

\subsubsection{Hypertext Preprocessor (PHP)}

Hypertext Preprocessor (PHP) adalah bahasa script yang ditanam di sisi server[9]. Processor PHP dijalankan di server (Windows atau Linux). Saat sebuah halaman dibuka dan mengandung kode PHP, processor itu akan menerjemahkan dan mengeksekusi semua perintah dalam halaman tersebut dan kemudian menampilkan hasilnya ke browser sebagai halaman HTML biasa. Karena penerjemahan ini terjadi di server, sebuah halaman yang ditulis dengan PHP dapat dilihat dengan menggunakan semua jenis browser, di sistem operasi apapun.

\subsubsection{MySQL}

MySQL adalah nama database server. Database adalah kumpulan informasi yang disimpan di dalam komputer secara sistematik sehingga dapat diperiksa menggunakan suatu program komputer untuk memperoleh informasi dari basisdata tersebut[10].

Database digunakan untuk menyimpan informasi atau data yang terintegrasi dengan baik dalam komputer. Untuk mengelola database diperlukan suatu perangkat lunak yang disebut Database Management System (DBMS). Database merupakan bagian dari DBMS yang menyediakan data dalam berbagai tipe dan format untuk memenuhi kebutuhan pemakai.

\section{3 Perancangan Sistem}

\subsubsection{Analisa Sistem yang Sedang Berjalan}

Analisis sistem yang ssedang berjalan dapat dilihat pada gambar 1 .

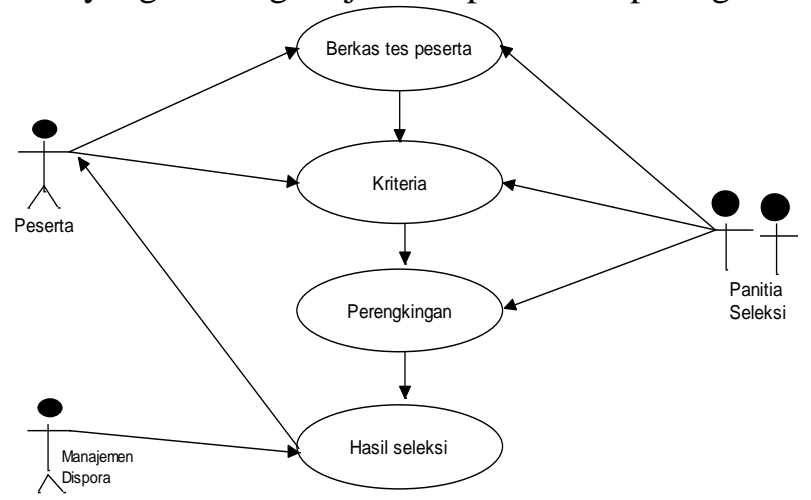

Gambar 1. Analisa Sistem Yang Sedang Berjalan

Penilaian seleksi penerimaan calon paskibraka nasional di provinsi riau masih manual menggunakan aplikasi Microsoft Office Excel dan banyak menyita waktu karena prosesnya yang cukup panjang. Proses tersebut dilakukan saat semua berkas hasil test seluruh peserta dikumpulkan oleh panitia seleksi kemudian penilaian diproses lebih lanjut. Proses tersebut dilakukan manual. Hasil penilaian akan dikoreksi lagi oleh tim panitia penerimaan paskibraka untuk menentukan nilai akhir seluruh peserta. Hasil 
penilaian tersebut kemudian dirapatkan kembali oleh petugas tim seleksi dan Kadispora untuk proses terakhir pengumuman hasil seleksi.

\subsubsection{Data Flow Diagram (DFD)}

Data Flow Diagram (DFD) digunakan untuk menjelaskan alur kerja dari sistem yang akan dibangun. Data flow diagram yang akan dirancang pada sistem pendukung keputusan seleksi calon Paskibraka Nasional di Provinsi Riau ini terdapat beberapa level proses, yaitu:

Pada gambar 2 adalah DFD level 0. Dari proses pertama login, login bisa dilakukan panitia atau petugas seleksi calon Paskibraka dan manajemen Dispora. Setelah login petugas dapat menginputkan data peserta, data kriteria, data penilaian, Selanjutnya data tersebut digunakan untuk perhitungan proses AHP oleh manajemen dispora setelah login, dan menghasilkan laporan hasil seleksi sebagai pertimbangan dalam mengambil keputusan

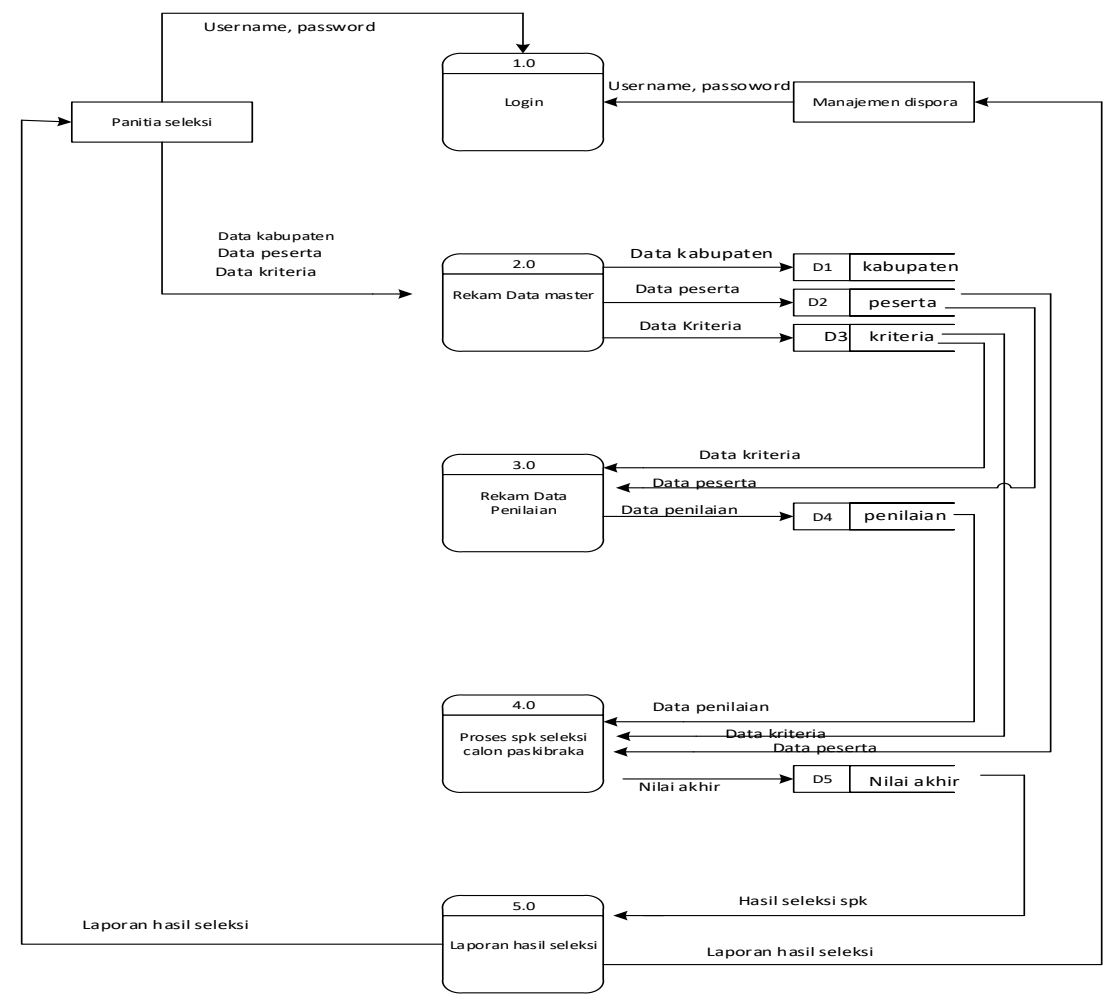

Gambar 2. Data Flow Diagram (DFD)

\subsubsection{DFD level 1 proses 4}

Pada gambar 3 merupakan proses seleksi atau perangkingan penilaian seleksi calon Paskibraka Nasional menggunakan metode AHP yang akan menentukan nilai akhir peserta. Dari hasil proses seleksi ini akan dijadikan acuan bagi pengambil keputusan yaitu manajemen Dispora untuk mengetahui peserta mana yang berhak mewakili Provinsi Riau di Istana Kepresidenan. Untuk lebih jelasnya dapat dilihat pada gambar 3. 


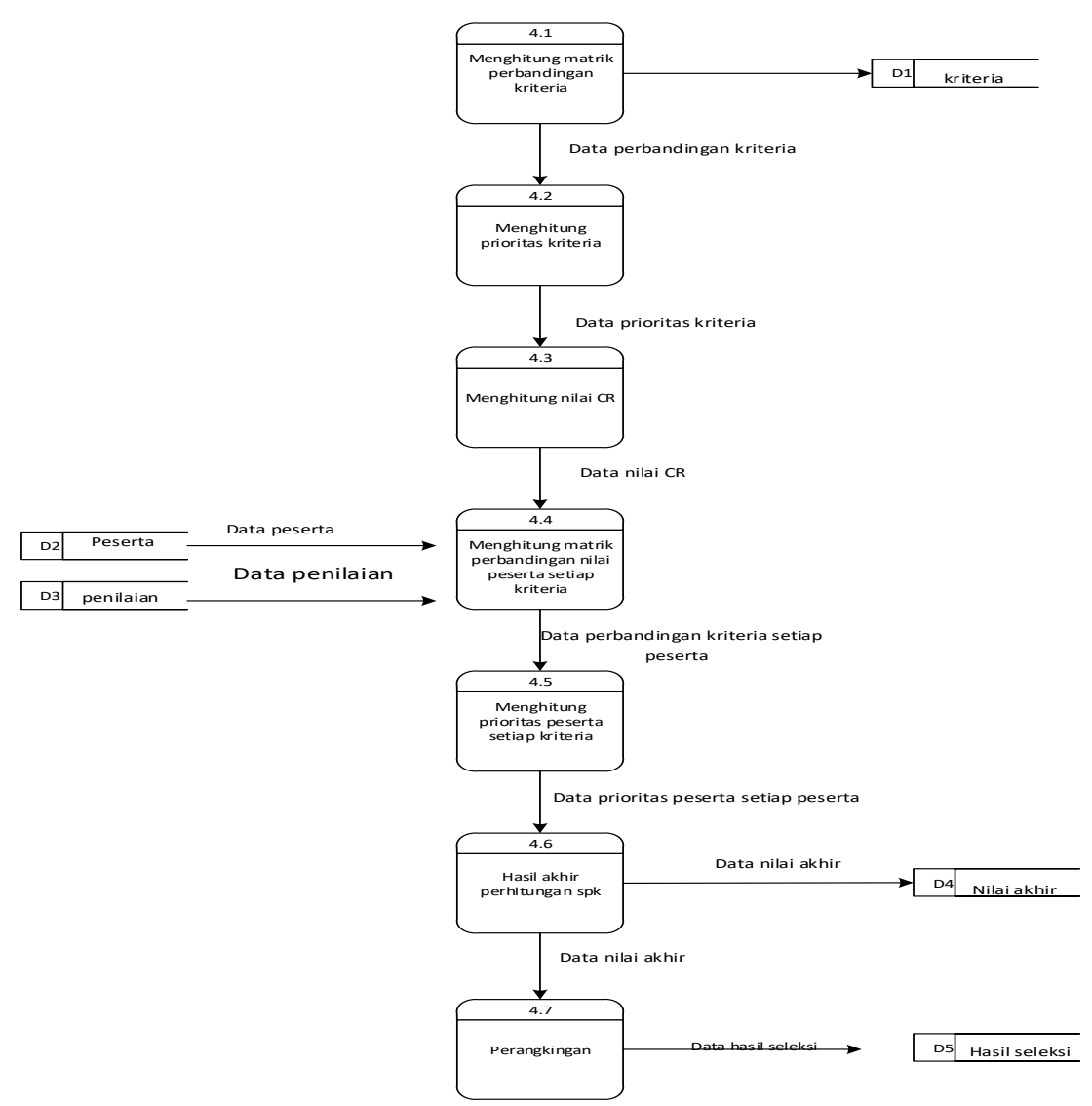

Gambar 3. Data Flow Diagram (DFD) Level 1 Proses 4

\subsection{4 flowchart}

Pada gambar 4 merupakan desain flowchart penentuan seleksi Paskibraka, dimana setelah data periode penerimaan yang dibuka diinputkan maka akan dilakukan input data yang ingin diseleksi. Tentukan prioritas kriteria, setelah prioritas kriteria didapatkan ulangi langkah penginputan data seleksi sampai mendapatkan hasil seleksi yang terpilih dari urutan tinggi sampai yang terendah. Kemudian cetak data peserta yang terpilih. 


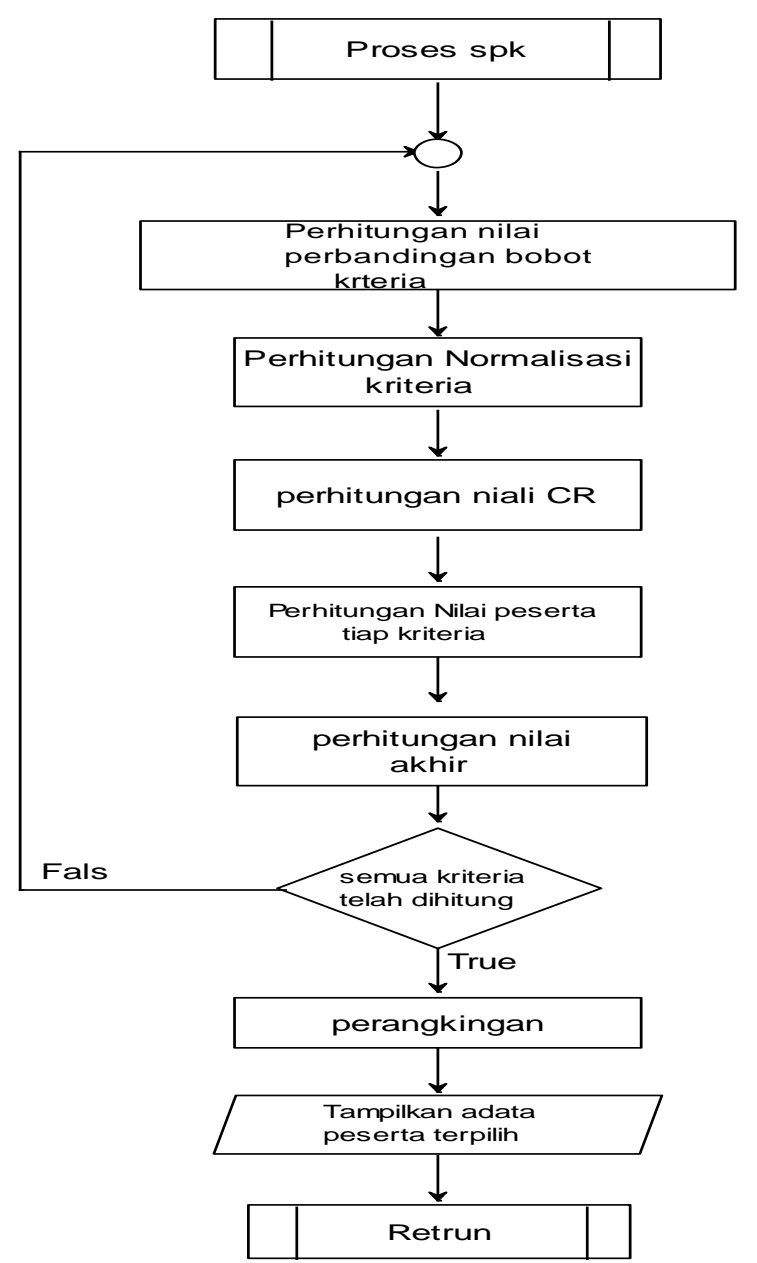

Gambar 4. Program Flowchart Proses SPK Metode AHP

\section{HASIL DAN PEMBAHASAN}

Penulis akan melakukan uji sistem terlebih dahulu sebelum sistem ini digunakan oleh pengguna, yakni oleh panitia seleksi dan kabid pemuda (Dispora). Pengujian dilakukan untuk memastikan sistem sudah berjalan seperti yang diharapkan. Panitia seleksi bertanggung jawab mengelola data peserta selepaspaskibraka Nasional. Sementara kabid pemuda memvalidasi laporan akhir seleksi paskibraka Nasional. 


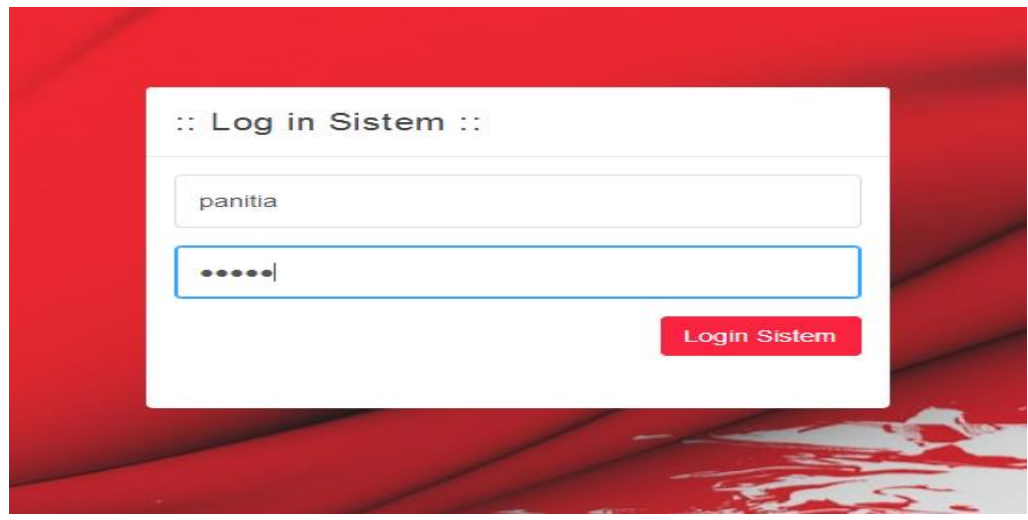

Gambar 5. Form Login "Username dan Password

Untuk dapat melakukan pengolahan data pada sistem, petugas seleksi harus login ke dalam sistem. Pengguna hanya tinggal memasukkan username dan password yang telah terdaftar ke sistem. Berikut gambar tampilan halaman login sistem ini dapat dilihat pada gambar 5 .

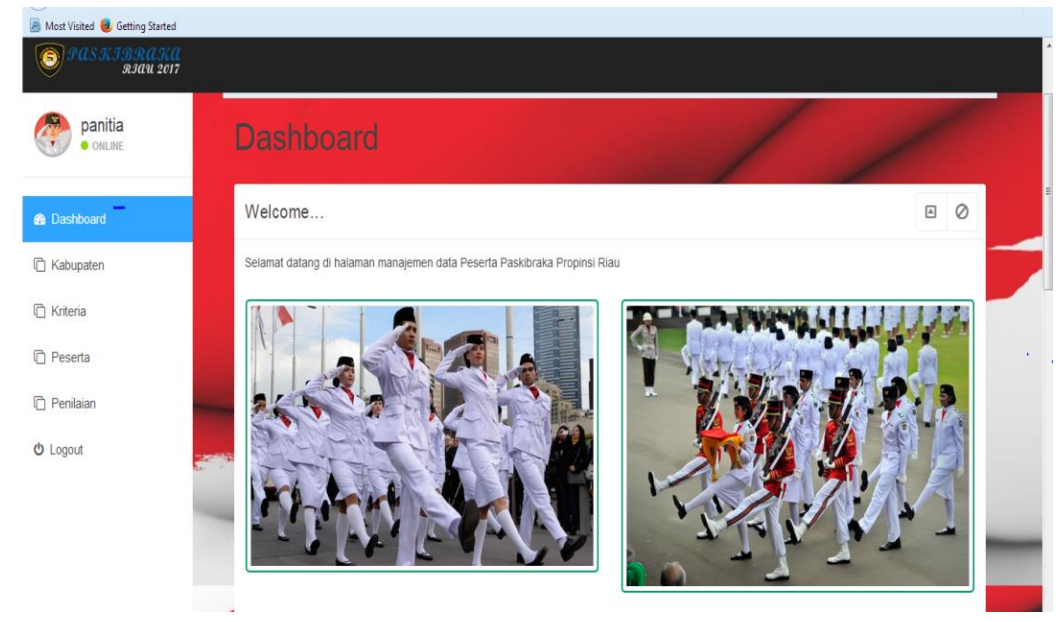

Gambar 6. Tampilan Menu Utama Panitia

Pada gambar 6. menyatakan bahwa login berhasil, data username dan password ditemukan, maka sistem akan menampilkan form menu utama panitia.

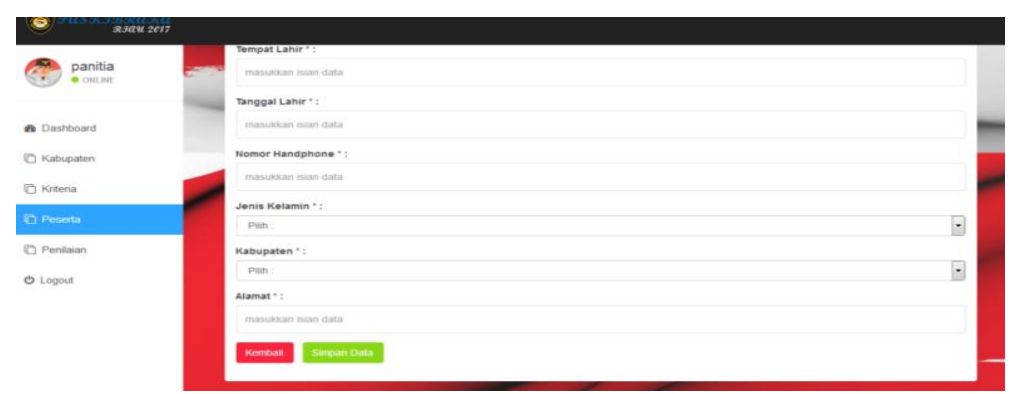

Gambar 7. Pengujian form Tamabah Data Peserta 


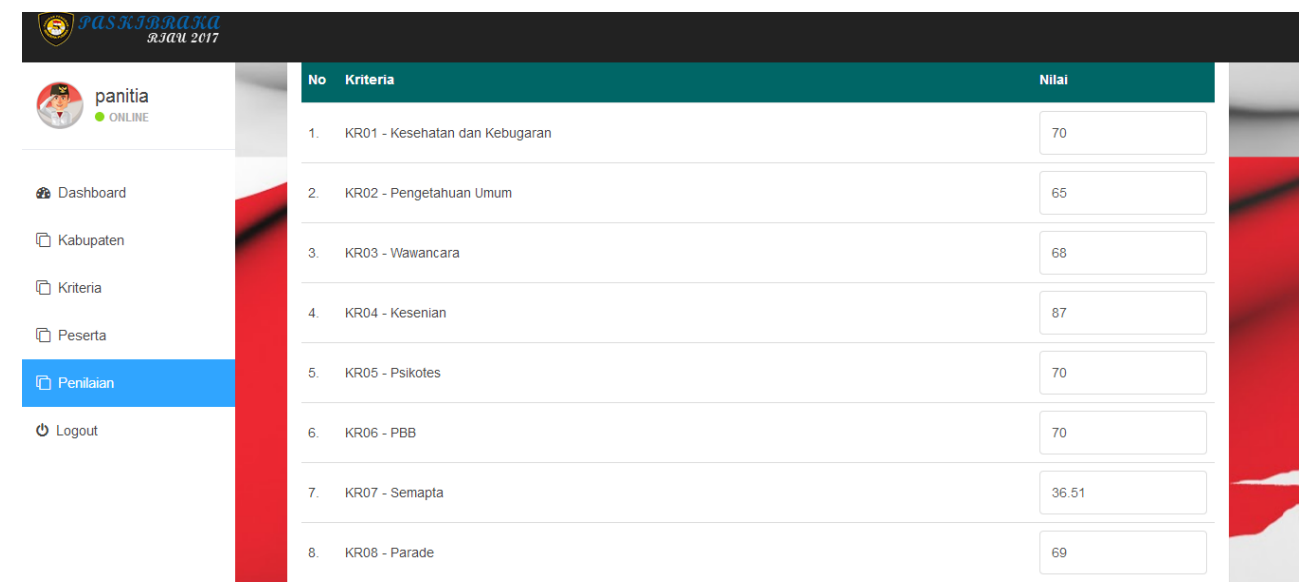

Gambar 8. Input Nilai Peserta

Gambar 8 adalah tampilan input nilai peserta pada setiap kriteria, apabila data setiap peserta selesai diinputkan maka data tersebut akan diproses oleh managemen dispora.berikut adalah tampilan data yang sudah diinputkan oleh penitia petugas seleksi.

Pada gambar 9 merupakan hasil perhitungan yang telah diproses dari hasil akhir tersebut dapat diketahui rangking peserta seleksi seperti pada.

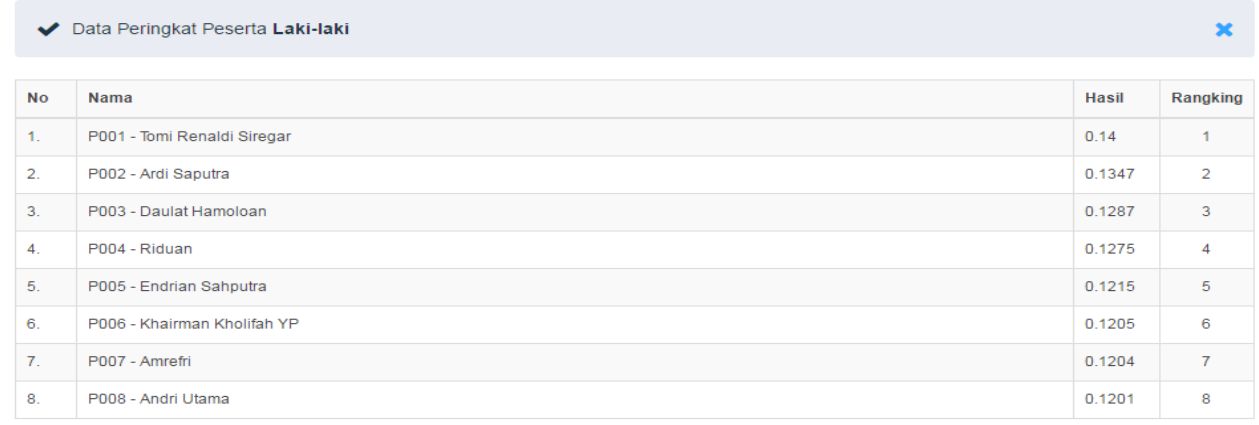

Gambar 9. Hasil Perangkingan

\section{KESIMPULAN}

Berdasarkan hasil analisa dan pembahasan yang telah dilakukan pada sistem pendukung keputusan pemilihan calon Paskibraka Nasional di Provinsi Riau dapat diambil kesimpulan sebagai berikut :

1. Telah berhasil dibangun sistem pendukung keputusan pemilihan peserta calon Paskibraka Nasional dengan menggunakan metode AHP.

2. Dengan adanya sistem ini dapat membantu petugas seleksi dan Dispora dalam menyeleksi calon peserta Paskibraka Nasional dengan akurat dan tepat.

3. Berdasarkan pengujian blackbox sistem pemilihan Paskibraka Nasional ini berjalan dengan semestinya. 
4. Setelah dilakukan uji coba sistem dapat disimpulkan bahwa penggunaan sistem ini mempermudah dalam melakukan proses pemilihan calon Paskibraka Nasional di Provinsi Riau.

\section{SARAN}

Adapun saran yang dapat diberikan untuk pengembangan sistem pendukung keputusan pemilihan calon Paskibraka Nasional ini sebagai berikut :

1. Dapat dikembangkan dengan menggunakan metode lain yang sesuai dengan kasus penelitian ini agar hasil yang didapatkan lebih maksimal.

2. Aplikasi sistem pendukung keputusan pemilihan Paskibraka Nasioanal ini agar nantinya dapat dikembangkan lagi dengan berbasis mobile dan menambahkan fitur SMS Gateway.

3. Aplikasi dapat dikembangkan lebih baik dengan tambahan desain dan flatform yang lebih bagus dari sebelumnya.

\section{DAFTAR PUSTAKA}

[1] Kementrian., 2015. Penyelenggaraan Kegiatan Pasukan Pengibar Bendera Pusaka

[2] Reza, M.Fairuz., 2014 Sistem Pendukung Keputusan Pemilihan Paskibraka dikota pekanbaru dengan metode Fuzzy Multy Attribute decision Making. Skripsi., Universitas Islam Negeri Riau.

[3] Fauzan,Arif,Muammar., 2010. Sistem Pendukung Keputusan Pemilihan Objek wisata dengan Menggunakan Metode AHP. Skripsi., Universitas Negeri Surabaya.

[4] Kusmono, Idam., 2011., Sistem Pendukung Keputusan Pemilihan Fakultas Dipeguruan Tinggi Berbasis Mobile. Jurnal Universitas Dian Suswantoro., : Semarang

[5] Kementrian., 2015. Penyelenggaraan Kegiatan Pasukan Pengibar Bendera Pusaka

[6] Kusrini., 2007. Konsep dan Aplikasi Sistem Pendukung Keputusan. Andi, Yogyakarta.

[7] Syaifullah., 2010, Pengenalan Metode Analytical Hierarchy Process (AHP), https://syaifullah08.files.wordpress.com/2010/02/pengenalan-analytical-hierarchyprocess.pdf, 8Agustus 2017.

[8] Sidik Betha., 2011. "JavaScript", Informatika Bandung, Bandung.

[9] Astamal, R. (2010). Modul Pemrograman PHP. Surabaya: Lug Stikom.

[10] Kadir, Abdul., 2013, Pemrograman Database MySQL, Mediakom, Yogyakarta 